\title{
A Study of Clinical Profile and Factors Influencing Outcome in Patients with Acute Kidney Injury
}

\author{
Moogaambiga Solai Raja Pandiyann ${ }^{1}$, Kirubhakaran Kanakaraju², \\ Rangabashyam Seetharaman Ranganathan ${ }^{3}$, Sheena Joseph Stanley Joseph ${ }^{4}$
}

1, 2, 3 Department of Medicine, Vinayaka Missions Kirupananda Variyar Medical College And Hospital, Salem, Tamil Nadu, India, ${ }^{4}$ Department of Medicine, Morris Mathias Hospital, Nagercoil, Vettunimadam, Tamil Nadu, India.

\section{ABSTRACT}

\section{BACKGROUND}

Acute kidney injury (AKI) is defined as the sudden impairment of renal function leading to retention of nitrogenous and other waste products normally cleared by the kidneys. The incidence of AKI during hospitalisation is estimated to be around 2 - 5 $\%$ and it complicates more than $50 \%$ of intensive care unit (ICU) admissions. Development of AKI results in increased morbidity and mortality in patients and it's an important negative prognostic factor in critically ill patients. So it is important to diagnose AKI early and study the clinical profile and factors influencing the outcome of AKI. The purpose of this study was to evaluate the clinical profile of AKI and determine the influence of clinical and laboratory factors on prognosis.

\section{METHODS}

We studied 50 patients who developed AKI during admission in Vinayaga Mission's Medical College and Hospital, Salem. Complete clinical examination and relevant investigations were done. Serum urea and creatinine was monitored for 5 days and at the time of discharge. All patients were treated conservatively and hemodialysis was done in those who required renal replacement therapy. The final outcome was assessed by whether there was complete or incomplete recovery of renal function.

\section{RESULTS}

Acute diarrhoeal illness (32 \%) was the major cause of AKI in our study followed by pneumonia (12\%) and snakebite (10\%). Magnitude of rise in serum urea and creatinine levels significantly influenced outcome in our patients. Hyperkalemia, requirement of dialysis and increased duration of hospital stay were other factors that showed poor prognosis.

\section{CONCLUSIONS}

Outcome of patients developing AKI depends upon the underlying cause as well as severity of renal insult. We should be aware of risk factors of AKI and clinical factors associated with poor outcome. AKI is better prevented than cured. It should be diagnosed early and treated aggressively to improve patient outcomes.
Corresponding Author: Dr. S. Moogaambiga, C1, Brindavan Vasantham Apartments, Perumal Malai Road, Narasothipatty, Salem - 636004, Tamil Nadu, India. E-mail:mooks.stanlean@gmail.com

DOI: $10.14260 / \mathrm{jemds} / 2021 / 556$

How to Cite This Article: Pandiyan MSR, Kanakaraju K, Ranganathan RS, et al. A study of clinical profile and factors influencing outcome in patients with acute kidney injury. J Evolution Med Dent Sci 2021;10(33):27232727, DOI: 10.14260/jemds/2021/556

Submission 08-04-2021, Peer Review 12-06-2021, Acceptance 19-06-2021, Published 16-08-2021.

Copyright (C) 2021 Moogaambiga Solai Raja Pandiyan et al. This is an open access article distributed under Creative Commons Attribution License [Attribution 4.0 International (CC BY 4.0)]

\section{KEY WORDS}

Acute Kidney Injury, Clinical Outcome, Hemodialysis 


\section{BACKGROUND}

Acute kidney injury, previously known as acute renal failure is characterized by the sudden impairment of kidney function resulting in the retention of nitrogenous and other waste products normally cleared by the kidneys. ${ }^{1} \mathrm{AKI}$ is defined as any one of the following criteria ${ }^{2}$

- Increase in Sr. creatinine by $0.3 \mathrm{mg} / \mathrm{dl}(\geq 26.5 \mu \mathrm{mol} / \mathrm{l})$ within 48 hours;

- Increase in Sr. creatinine to 1.5 times baseline, which is known or presumed to have occurred within the prior 7 days

- Urine volume $<0.5 \mathrm{ml} / \mathrm{kg} / \mathrm{h}$ for 6 hours.

The incidence rate of AKI during hospitalisation is estimated to be around $2-5 \%$ and can be attributed to diarrhoeal illnesses, infections, envenomations and increasing prevalence of diabetes. AKI complicates more than $50 \%$ of intensive care unit admissions. ${ }^{3}$ It is not limited to medical ICU but also seen in post trauma cases, post-operative cases in surgical ICU and in obstetric cases in obstetric ICU. Based on the etiology and management, it is broadly classified into three categories pre-renal, renal and post-renal. ${ }^{4}$

The initial approach to a patient with AKI is to identify and address the underlying cause and provide supportive treatment for fluid and electrolyte imbalance. Dialysis is used as an extension of supportive measure. Development of AKI results in increased mortality in hospitalised patients especially in an ICU setting where the mortality exceeds 50 $\%{ }^{5,6}$ Morbidity due to AKI is determined by the severity of AKI and underlying disease. In addition factors like age, presence of comorbidities, life threatening complications like hyperkalemia, cardiac arrhythmia, pulmonary edema, myocardial infarction, and bleeding tendencies also influence patient survival. Patients who require dialysis have even greater morbidity. It is clear that ICU and in-hospital mortality rate increase in direct proportion to the severity of AKI.7,8 Hence AKI is an important negative prognostic factor, particularly in critically ill patients. Even a minimal increase in serum creatinine results in significant increase in short term morbidity and mortality and in long term outcomes including one year mortality. ${ }^{9-11}$

Studies have found that the mortality rate was $15.2 \%$ in patients with primary AKI whereas it was $32.6 \%$ in patients with AKI as secondary diagnosis in addition to other problems.12 This shows that an isolated AKI has a better prognosis than AKI in the setting of multi-organ failure.

A patient with normal baseline renal function, after developing AKI could end in full recovery, incomplete recovery resulting in chronic kidney disease (CKD) or non-recovery of function leading to end stage renal disease. On the other hand a CKD patient after developing AKI may result in exacerbation of CKD ending up in end stage renal disease (ESRD).13 CKD patients are at increased risk of developing an acute kidney injury compared to normal population. Therefore we are able to understand that AKI and CKD are risk factors for each other. ${ }^{14}$ So, it is important to identify episodes of AKI early as well as study the clinical profile and factors influencing the outcome of AKI.

\section{METHODS}

This prospective study was conducted at Vinayaka Missions Medical College and Hospital, Salem from June 2018 to May 2019. We got approval from Institutional Ethical Committee and obtained informed consent from all the patients. We wanted to study the clinical profile of AKI and determine the influence of clinical and laboratory factors on prognosis of patients developing acute kidney injury during hospital stay. Adult male patients with baseline creatinine $0.6-1.2 \mathrm{mg} / \mathrm{dl}$ and adult female patients with baseline creatinine $0.5-1.1$ $\mathrm{mg} / \mathrm{dl}$, who developed AKI after hospital inpatient admission were included in the study. Patients whose creatinine increased by $0.3 \mathrm{mg} / \mathrm{dl}$ in 48 hours or creatinine increased from 1.5 times the baseline were selected. Patients with previous history of chronic kidney disease and patients with evidence of contracted kidneys in ultrasonography (USG) abdomen were excluded. A total of 50 patients were included as our study subjects.

Non-probability sampling -purposive sampling was used to select patients. For all the patients who had been diagnosed with acute kidney injury, serum urea and serum creatinine was tested during their first 5 days of their hospital stay and subsequently at the time of discharge.

A complete physical examination and routine blood investigations were done. Additional investigations like blood for leptospiral antibody, malarial smear, blood culture and sensitivity, arterial blood gases depending on the cause of AKI were also done. All patients were treated conservatively based on their symptoms and the cause for acute kidney injury. If the patients did not improve with conservative management, renal replacement therapy in the form of hemodialysis was done. The final outcome was measured in the form of whether the patient recovered completely or not. Complete recovery was considered when the patient's serum creatinine levels return to within $50 \%$ of the baseline levels. ${ }^{15}$

\section{Sample Size}

Formula. $\mathrm{N}=4^{*} \mathrm{p}^{*} \mathrm{q} / \mathrm{d}^{*} \mathrm{~d}$

Where $\mathrm{p}=2.1 \%$ (based on study done by Goswami et al.)

$\mathrm{Q}=100-2.1=97.9$

$\mathrm{D}=5 \%$

$\mathrm{N}=33+10 \%$ non-response error.

Sampling was done by convenience sampling method.

\section{Statistical Analysis}

Collected data was entered in Microsoft Excel and analysed using Statistical Package for Social Sciences (SPSS version 22.0). Descriptive statistics data was interpreted in frequency and percentage and difference in proportion was tested using chi square test.

\section{RESULTS}

Majority of the study subjects were in the age group between 60 and 70 years and the mean age among them was 53.3 years. 
Among the study subjects, 28 were males and 22 were females. Males are slightly more in number than the females with a male : female ratio of $1.27: 1$. No statistically significant association between the age and the clinical outcome was found ( $\mathrm{P}>.05)$. The most common cause for AKI was found to be acute gastroenteritis with dehydration (26\%) followed by pneumonia with sepsis (12\%) and snake bite (10\%) (Table 1). Poisoning, hemorrhage and road traffic accidents (RTA) were few other causes leading to acute kidney injury in the study subjects. It is inferred from the table that the most common etiological factor like acute gastroenteritis with dehydration and pneumonia with sepsis showed a complete recovery. One patient each with etiology of snake bite, RTA with hypotension and shock, leptospirosis, intracerebral bleed and urosepsis showed a poor recovery status.

Oliguria (66\%) and fever (62\%) were found to be the most common symptom followed by vomiting (38\%) and abdominal pain (32\%). $22 \%$ had breathlessness and $6 \%$ had altered sensorium. The most common co-morbid condition was type II diabetes mellitus (DM) followed by hypertension and coronary artery disease. $36 \%$ of the subjects did not have any co-morbid conditions. No statistically significant association was seen between the presence of co-morbidity and the clinical outcome. The incidence of hyperkalemia was found to be $20 \%$. The presence of hyperkalemia showed a poor recovery status and this association was found to be statistically significant $(\mathrm{P}<.05)$. (Table 2$)$

\begin{tabular}{|c|c|c|}
\hline Cause for AKI & $\begin{array}{l}\text { Complete Recovery } \\
\text { (n= 43) } 86 \%\end{array}$ & $\begin{array}{l}\text { Not Recovered } \\
(n=7) 14 \%\end{array}$ \\
\hline AGE with dehydration $(n=13) 26 \%$ & 13 & 0 \\
\hline $\operatorname{AGE}(n=3) 6 \%$ & 3 & 0 \\
\hline Pneumonia with sepsis $(n=6) 12 \%$ & 6 & 0 \\
\hline $\begin{array}{l}\text { Road traffic accident with hypotension } \\
\qquad(\mathrm{n}=3) 6 \%\end{array}$ & 2 & 1 \\
\hline $\begin{array}{l}\text { Road traffic accident with septic shock } \\
\qquad(\mathrm{n}=3) 6 \%\end{array}$ & 2 & 1 \\
\hline Snake bite $(n=5) 10 \%$ & 4 & 1 \\
\hline Urosepsis (n = 3) $6 \%$ & 2 & 1 \\
\hline Cellulitis with sepsis $(n=2) 4 \%$ & 2 & 0 \\
\hline OPC poisoning $(n=2) 4 \%$ & 2 & 0 \\
\hline Cancer breast with sepsis $(\mathrm{n}=1) 2 \%$ & 1 & 0 \\
\hline GI perforation $(n=1) 2 \%$ & 0 & 1 \\
\hline Gluteal abscess with sepsis $(n=1) 2 \%$ & 1 & 0 \\
\hline Glyphosate poisoning $(n=1) 2 \%$ & 1 & 0 \\
\hline Leptospirosis $(n=1) 2 \%$ & 0 & 1 \\
\hline $\begin{array}{l}\text { Intracerebral hemorrhage with sepsis } \\
\qquad(\mathrm{n}=1) 2 \%\end{array}$ & 0 & 1 \\
\hline Paraquat poisoning $(\mathrm{n}=1) 2 \%$ & 1 & 0 \\
\hline $\begin{array}{l}\text { Postpartum hemorrhage with septic } \\
\text { shock }(\mathrm{n}=1) 2 \%\end{array}$ & 1 & 0 \\
\hline $\begin{array}{l}\text { Total hip replacement with sepsis }(n= \\
\text { 1) } 2 \%\end{array}$ & 1 & 0 \\
\hline $\begin{array}{l}\text { Variceal bleeding with portal } \\
\text { hypertension }(n=1) 2 \%\end{array}$ & 1 & 0 \\
\hline \multicolumn{3}{|c|}{ Table 1: Aetiology of the AKI and Their Clinical Outcome } \\
\hline
\end{tabular}

\begin{tabular}{|ccccc|}
\hline Hyperkalemia & $\begin{array}{c}\text { Complete } \\
\text { Recovery }(\mathbf{n}= \\
\mathbf{4 3})\end{array}$ & $\begin{array}{c}\text { Not Recovered } \\
(\mathbf{n}=7)\end{array}$ & $\begin{array}{c}\text { Pearson } \\
\text { Chi-Square } \\
\text { Value }\end{array}$ & P Value \\
Present $(\mathrm{n}=10)$ & 3 & 7 & 32.55 & $<.0001$ \\
\hline Absent $(\mathrm{n}=40)$ & 40 & 0 & & \\
\hline \multicolumn{5}{|r}{ Table 2. Hyperkalemia and Clinical Outcome } \\
among the Study Subjects
\end{tabular}

Among the study subjects, $88 \%$ (44 patients) underwent a conservative line of management and the remaining $12 \%$ of patients (6 patients) required hemodialysis in addition to other supportive therapy. Among total cases, $86 \%$ of the patients had recovered completely and only $14 \%$ did not recover completely. Most of the patients who were treated conservatively, recovered completely, on the other hand 6 patients who required hemodialysis, did not recover completely. A statistically significant association was seen between the mode of treatment and the recovery status $(\mathrm{P}<$ .05) (Table 3). Table 4 shows the blood urea level on the 2 nd day and the clinical outcome of the study subjects. The rise of urea level was seen from the 2nd day and so it was taken to assess the clinical outcome. It is inferred from the table that lesser the urea levels better the recovery and a statistical significant association was seen between 2 nd day urea levels and their clinical outcome $(\mathrm{P}<.05)$.

Table 5 shows the blood creatinine level on the 2nd day and the clinical outcome of the study subjects. Similar to the urea levels, creatinine was also seen to increase from day 2 . It is inferred from the table that lesser the creatinine levels better the recovery and a statistical significant association was found between patient creatinine levels and their clinical outcome $(\mathrm{P}<.05)$. Out of 50 patients, 13 stayed in hospital for less than 10 days, 23 stayed for 10 - 20 days and 13 stayed for more than 20 days. Among the 7 patients who did not recover completely, 6 had stayed in the hospital for more than 20 days. It was found that longer the duration of hospital stay, poorer the prognosis. This association between the duration of hospital stay and outcome of AKI was found to be statistically significant.

\begin{tabular}{|ccccc|}
\hline $\begin{array}{c}\text { Mode of } \\
\text { Treatment }\end{array}$ & $\begin{array}{c}\text { Complete } \\
\text { Recovery } \\
(\mathbf{n}=\mathbf{4 3})\end{array}$ & $\begin{array}{c}\text { Not Recovered } \\
(\mathbf{n}=7)\end{array}$ & $\begin{array}{c}\text { Pearson } \\
\text { Chi-Square } \\
\text { Value }\end{array}$ & P Value \\
$\begin{array}{c}\text { Conservative }(\mathrm{n}= \\
\text { 44) }\end{array}$ & 43 & 1 & 41.88 & $<.0001$ \\
$\begin{array}{c}\text { Hemodialysis }(\mathrm{n}= \\
\text { 6) }\end{array}$ & 0 & 6 & & \\
\hline \multicolumn{4}{|c|}{ Table 3. Mode of Treatment and Clinical Outcome } \\
\hline
\end{tabular}

\begin{tabular}{|c|c|c|c|c|}
\hline $\begin{array}{c}\text { Blood Urea } \\
\text { Levels }(\mathrm{mg} / \mathrm{dl})\end{array}$ & $\begin{array}{c}\text { Complete } \\
\text { Recovery }(n= \\
43)\end{array}$ & $\begin{array}{l}\text { Not Recovered } \\
(n=7)\end{array}$ & $\begin{array}{c}\text { Pearson } \\
\text { Chi-Square } \\
\text { Value }\end{array}$ & P Value \\
\hline$<40(\mathrm{n}=1)$ & 1 & 0 & \multirow{6}{*}{20.970} & \multirow{6}{*}{0.001} \\
\hline $41-60(n=9)$ & 9 & 0 & & \\
\hline $61-80(n=15)$ & 14 & 1 & & \\
\hline $81-100(n=14)$ & 13 & 1 & & \\
\hline $101-120(\mathrm{n}=6)$ & 5 & 1 & & \\
\hline $\begin{array}{r}\quad 120(\mathrm{n} \\
=5)\end{array}$ & 1 & 4 & & \\
\hline \multicolumn{5}{|c|}{$\begin{array}{l}\text { Table 4. Blood Urea Level on the } 2^{\text {nd }} \text { Day } \\
\text { and the Clinical Outcome of the Study Subjects }\end{array}$} \\
\hline
\end{tabular}

\begin{tabular}{|c|c|c|c|c|}
\hline $\begin{array}{c}\text { Blood } \\
\text { Creatinine } \\
\text { Levels } \\
\text { (mg/dl) }\end{array}$ & $\begin{array}{c}\text { Complete } \\
\text { Recovery }(n= \\
43)\end{array}$ & $\begin{array}{l}\text { Not Recovered } \\
(\mathbf{n}=7)\end{array}$ & $\begin{array}{c}\text { Pearson } \\
\text { Chi-Square } \\
\text { Value }\end{array}$ & P Value \\
\hline$<1.2(\mathrm{n}=2)$ & 2 & 0 & \multirow{5}{*}{23.25} & \multirow{5}{*}{$<.001$} \\
\hline $\begin{array}{c}1.21-2.0(\mathrm{n}= \\
33)\end{array}$ & 32 & 1 & & \\
\hline $2.1-3.0(\mathrm{n}=12)$ & 9 & 3 & & \\
\hline $3.1-4.0(\mathrm{n}=2)$ & 0 & 2 & & \\
\hline $4.1-5.0(\mathrm{n}=1)$ & 0 & 1 & & \\
\hline
\end{tabular}

\section{DISCUSSION}

This study was conducted to assess the clinical profile and outcome of patients with acute kidney injury. Impairment of renal functions is a serious complication in critically ill patients. Mortality of patients with oliguric and nonoliguric AKI remains in the $35 \%$ to $86 \%$ and $10 \%$ to $30 \%$ ranges respectively despite substantial improvement in haemodialysis techniques. The mean age of the patients in the 
present study was 53.3 years. Males were slightly more than number of females.

Oliguria (66\%), fever (62\%), vomiting (38\%), abdominal pain $(36 \%)$ were the most common clinical symptoms in acute kidney injury. Other studies too report similar common symptoms in AKI. ${ }^{16,17}$ In addition, diarrhoea was found in 32 $\%$ of the patients probably because acute gastroenteritis with dehydration was the major cause of AKI in our study patients.

The most common cause for AKI was found to be acute gastroenteritis with dehydration (26\%) followed by pneumonia with sepsis (12\%) and snake bite (10\%). Poisoning, hemorrhage and road traffic accidents were the few other causes leading to acute kidney injury in the study subjects. In the current study, $14 \%$ of the patients had AKI due to surgical cause and the remaining were pertaining to medical causes and it was almost in par with the study done by Muthusethapatti MA et al. in a hospital at Chennai study titled "Study on acute renal failure in south India".18

In the present study, $42 \%$ of the patients had either diabetes, hypertension or both as comorbidity and $12 \%$ of them had coronary artery disease (CAD). In our study, we didn't find a statistically significant association between the presence of comorbidity and the clinical outcome. This might be due to the fact that snake bite, road traffic accidents in spite of occurring in patients without comorbidities resulted in incomplete recovery due to the severity of renal injury.

In the current study, presence of hyperkalemia showed a poor recovery status and this association was found to be statistically significant. Other studies in AKI also report a significant association between the presence of hyperkalemia initially and poor recovery among patients with AKI. ${ }^{19}$

In our study, $88 \%$ of patients were treated conservatively and $12 \%$ were taken for hemodialysis. The main indications for dialysis were refractory hyperkalemia, severe metabolic acidosis and uraemic encephalopathy. Requirement of dialysis was found to be a negative prognostic factor as all the 6 patients who required dialysis ended up in incomplete recovery. This is in accordance with the fact that more severe the acute kidney injury, the more is the chance of requiring hemodialysis. Serum urea and creatinine usually rise above upper normal limits only after $50 \%$ reduction in glomerular filtration rate. In our study, serum levels of urea and creatinine on day 2 was found to influence the outcome of the patient. Hence, the magnitude of rise in urea and creatinine in a patient with acute kidney injury is an important prognostic factor. Similar studies have found that increasing urea and creatinine levels in spite of conservative treatment showed poor survival outcomes. $^{20}$ The duration of stay in hospital also helps in predicting the outcome. The longer the duration of stay, higher the chances of patient ending up with incomplete recovery. The severity of renal injury determines the duration of treatment required as well as the time required for renal function to return to baseline.

\section{CONCLUSIONS}

Acute kidney injury is a medical complication that has to be identified early. Early diagnosis and intervention determines the outcome. Awareness about the risk factors and precipitating factors is required both to prevent as well as identify acute kidney injury early. Acute gastroenteritis with dehydration and sepsis are the leading causes of AKI in this community, with acute gastroenteritis showing better prognosis and sepsis showing poor prognosis in AKI. Along with sepsis, patients with comorbid conditions like diabetes and hypertension, presence of multi organ dysfunction and with high baseline urea, creatinine and potassium levels influence poor clinical outcome among patients with AKI Because of the morbidity and mortality associated with acute kidney injury, it is important for primary care physicians to identify patients who are at high risk of developing acute kidney injury and take adequate preventive measures. However, more descriptive studies with increased sample size are required to increase the power of the study.

Data sharing statement provided by the authors is available with the full text of this article at jemds.com.

Financial or other competing interests: None.

Disclosure forms provided by the authors are available with the full text of this article at jemds.com.

\section{REFERENCES}

[1] Longo D, Fauci A, Kasper D, et al. Harrison's Principles of Internal Medicine. 18 ${ }^{\text {th }}$ edn. 2012: p. 2293.

[2] Acute Kidney Injury Work Group. KDIGO clinical practice guideline for acute kidney injury. Kidney International Supplements 2012;2(1):138.

[3] Ronco C, Bellomo R, Kellum JA. Acute kidney injury. Lancet 2019;394(10212):1949-64.

[4] Schrier RW, Wang W, Poole B, et al. Acute renal failure: definitions, diagnosis, pathogenesis and therapy. J Clin Invest 2004;114(1):5-14.

[5] Chertow GM, Burdick E, Honour M, et al. Acute kidney injury, mortality, length of stay and costs in hospitalized patients. J Am Soc Nephrol 2005;16(11):3365-70.

[6] Zimmerman JE, Wagner DP, Draper EA, et al. Evaluation of acute physiology and chronic health evaluation III predictions of hospital mortality in an independent database. Crit Care Med 1998;26(8):1317-26.

[7] Mehta RL, Pascual MT, Soroko S, et al. Spectrum of acute renal failure in the intensive care unit: the PICARD experience. Kidney Int 2004;66(4):1613-21.

[8] Uchino S, Kellum JA, Bellomo R, et al. Acute renal failure in critically ill patients: a multinational, multicenter study. JAMA 2005;294(7):813-8.

[9] United States Renal Disease Survey. United States renal data system annual data report. Minneapolis, MN: USRDS Coordinating Center 2006.

[10] Bagshaw SM, Laupland KB, Doig CJ, et al. Prognosis for long-term survival and renal recovery in critically ill patients with severe acute renal failure: a populationbased study. Crit Care 2005;9(6):R700-9.

[11] Praught ML, Shlipak MG. Are small changes in serum creatinine an important risk factor? Curr Opin Nephrol Hypertens 2005;14(3):265-70.

[12] Xue JL, Daniels F, Star RA, et al. Incidence and mortality of acute renal failure in medicare beneficiaries, 1992 to 2001. J Am Soc Nephrol 2006;17(4):1135-42.

[13] Okusa MD, Chertow GM, Portilla D, et al. The nexus of acute kidney injury, chronic kidney disease and World Kidney Day 2009. Clin J Am Soc Nephrol 2009;4(3):520-2. 
[14] Chawla LS, Amdur RL, Amodeo S, et al. The severity of acute kidney injury predicts progression to chronic kidney disease. Kidney Int 2011;79(12):1361-9.

[15] Bellomo R, Ronco C Kellum JA, et al. Acute renal failuredefinition, outcome measures, animal models, fluid therapy and information technology needs: the second International Consensus Conference of the Acute Dialysis Quality Initiative (ADQI) Group. Crit Care 2004;8(4):R204-12.

[16] Singhal AS, Salkar AR, Chaudhary A, et al. Clinical profile of acute renal failure. JAPI 2002;50:70-3.

[17] Khan Y, Deepak P, Kumar AP, et al. Study of etiology, clinical profile and outcome of acute kidney injury (AKI) in medical intensive care unit. International Journal of Contemporary Medical Research 2017;4(11):2225-8.

[18] Muthusethupathi MA, Shivakumar S. Acute renal failure in south India. Our experience with 187 patients. J Assoc Physicians India 1987;35(7):504-7.

[19] Gao XP, Zheng CF, Liao MQ, et al. Admission serum sodium and potassium levels predict survival among critically ill patients with acute kidney injury: a cohort study. BMC Nephrol 2019;20(1):311.

[20] Usman VS, Narayan R. Clinical profile, outcome and prognostic factors of acute kidney injury-a tertiary hospital based study. Galore International Journal of Health Sciences Research 2019;4(4):91-8. 